\title{
Tales of Social Terror: Notes on Argentine Working-Class Literature
}

Anna Björk Einarsdóttir

The term working-class literature is not widely used within Argentine literary studies, nor is it central to Latin American literary studies. ${ }^{\mathrm{I}}$ This essay takes up the problem of discussing workingclass literature in a context marked by the absence of the term. When examining works associated with the working class and the working-class struggle in Argentina, one is more likely to encounter expressions such as "the social novel" [la novela social], "social literature" [literatura social], "proletarian literature" [literatura proletaria], and even the more specific designation "Boedoliterature" [literatura boedista or boedismo]. ${ }^{2}$ This essay seeks to locate the starting point for a discussion devoted to Argentine working-class literature. In short, the aim here is to treat what at first glance may appear as the most important theme associated with working-class literature in Argentina. This theme is best described by citing literary and cultural critic Beatriz Sarlo's influential reading of Argentine writer Elías Castelnuovo, whose narratives she analyzes as "scientific fictions of social terror" (I988, p. 20I). As discussed in more detail below, critics have identified "social terror" as central to I920s and 30 s Argentine proletarian literature. However, this understanding of proletarian literature - and, by extension, working-class literature — poses problems. For example, authors who elsewhere would belong to the tradition of working-class literature are not considered as such within Argentine letters. The following discussion moves beyond local terminology and critical accounts, seeking to open up a new space to examine what might be categorized as Argentine working-class

How to cite this book chapter:

Einarsdóttir, A. B. 2020. Tales of Social Terror: Notes on Argentine Working-Class Literature. In: Lennon, J. and Nilsson, M. (eds.) Working-Class Literature(s): Historical and International Perspectives. Volume 2. Pp. I5-47. Stockholm: Stockholm University Press. DOI: https://doi.org/Io.I6993/bbf.b. License: CC-BY 4.0. 
literature. Furthermore, the essay recognizes the historical context in which the conventional critical narratives were formed while demonstrating how these narratives have shaped Argentine literature and its representations of the working class.

The social terror that has been identified as a major theme of I 920 and 3 os proletarian - or, "social" - literature turns out to be a prevalent mood of Argentine literature at least since Esteban Echeverrías's El matadero [The Slaughter Yard] (I87I). El matadero is considered the first work of prose fiction within Argentine literature and is well known for the portrayal of the lower classes as a violent horde. In the story, a young gentleman is brutally attacked and sodomized by a horde of starving poor people who are depicted unfavorably as supporters of Argentina's first dictator Juan Manuel de Rosas (I793-I 877). ${ }^{3}$ The vicious scene of butchery and gore in El matadero offers a pessimistic and brutal view of the lower classes. El matadero is quite remarkable, and, as María Teresa Gramuglio points out, if one accepts the story as the first work of prose fiction within Argentine letters, then "one would also have to admit that Argentine literature is born realist" (2002, p. 23). ${ }^{4}$ Moreover, and adding to Gramuglio's claim, this realism is infused with a pessimism characterized by brutal violence and social terror particularly prevalent in depictions of the working poor and members of the proletariat.

As opposed to other national traditions that see the emergence of literature concerned with the working class in the I9th century, Argentine literature is remarkable as few precursors exist prior to the appearance of the militant and workerist tradition of the Boedo-group in the I920s. This group forms an integral part of the proletarian moment of the I920s and the 30 s, initiating what should be considered the earliest expression of working-class literature in Argentina. The repression of the proletarian-centered interwar left took place earlier in Argentina than elsewhere. In I930, president Hipólito Yrigoyen was ousted in a coup d'état by José Félix Uriburo, thus initiating "the infamous decade" [la decada infame]. Uriburo's dictatorship repressed communist and leftists presses while imprisoning poets and writers, thus offering an early example of the repression that the communist left of the interwar period experienced in the mid-I93os and throughout 
the 40 s in other national contexts. Furthermore, the recovery of the old interwar literary left, which began elsewhere with the new left of the 6os and the 70 s and continued throughout the I980s and the 9os, was interrupted in Argentina with the brutal repression of the new left. During the military dictatorship of the I970s, leftist organizing and activism were suppressed along with artistic and literary radicalism, including attempts to recover neglected literature of the past.

While in other national contexts, this period saw the increased interest and recouping of the proletarian moment of the I920s and the 30 s, in Argentina, this time was characterized by state terror, forced imprisonment, torture, the killing of political dissidents, and exile. It is difficult to overstate the importance of this historical and political context for the fate of working-class literature within Argentine letters-especially when compared with traditions where working-class literature has been celebrated and accepted as forming a part of the national tradition. For example, in the Nordic countries, working-class literature has been recognized as a strand within the national literature and has even been canonized, in particular in Sweden (Nilsson, 20I7, pp. 95-96). Furthermore, in studies on American literature, specific attention has been paid to cultural production during the depression-era with the thirties playing a prominent role in scholarship since the early I990s initiating a recovery of proletarian literature and writings (Denning, 2010; Foley I993; Rabinowitz I996). In contrast, the attention to the atrocities of the military dictatorship and the complete repression and diffusion of the new left in Argentina has resulted in the devotion of Argentine literary studies to the recovery of the new left more than the old.

In Latin American literary studies, proletarian literature of the interwar period and the broader tradition of working-class literature have not been examined in a transnational context. Although the avant-garde movements have been studied in such context (Unruh, I994; Verani, I996), and some authors associated with the proletarian literary left have been folded into that discussion, ${ }^{5}$ there is currently no comprehensive study tracking the proletarian literary left in Latin America, nor are there transnational studies on working-class literature. The following discussion is primarily 
concerned with Argentine working-class literature and the question of how to approach the study of such literature in a context wherein the term does not possess a hegemonic place. Although this essay looks closely at a case of an isolated national literature, the aim is to contribute to the mapping of working-class literature across the region and beyond. This discussion urges for the study of the proletarian-centered literary left of the I920s and the 3 os across the region and in context of the international movement, for such literature found expressions in different corners of the world during that period. ${ }^{6}$ In particular, this article will focus upon Argentine proletarian writer Elías Castelnuovo and his role in shaping how not only proletarian literature but also how working-class literature is defined within Argentine letters. The following discussion moves chronologically, paying particular attention to the proletarian literary left of the 1920 s and the 305 and how this left and its critical legacy have shaped both Argentine literature and its criticism throughout the 2oth century. A recent example of this lineage includes discussions devoted to labor and the laboring body in contemporary Argentine literature. In recent scholarship, more attention has been paid to representations of labor in literature than working-class literature devoted to the struggle against labor (Rodríguez \& Laera, 20I9, p. 33).

\section{Institutionalized Tales of Social Terror}

In Argentina, the late I 800 s and the early I 900 s saw waves of immigration from Europe. Thus, the modern Argentine nation-state was formed in a context marked by the struggle over who belonged to the nation. ${ }^{7}$ The 1800 s saw the early development of national literature in José Mármol's Amalia (I85I) and Domingo Faustino Sarmiento's Facundo: Civilización y Barbarie (I 845) [Facundo: Civilization and Barbarism], culminating in José Hérnandez's epic poem Martin Fierro (I 872/79). The poem mythologized the gaucho, an early representative of a waged seasonally employed laborer on landed estates, skilled in horsemanship and cattle work. If portraying labor and the laborer is the defining feature of working-class literature, Martín Fierro could qualify as an early example of Argentine working-class literature. However, the poem does so in the absence of a working-class movement or before the 
Argentine labor movement fully emerged. ${ }^{8}$ As Neil Larsen points out, "Hernandéz discloses all the lineaments of proletarianization in Martín Fierro but evidently lacks its concept" (I995, p. I 5 I). Classifying works such as Martín Fierro as working-class literature, thus, poses certain problems for the discussion. Moreover, by the early I920s, the epic portrayal of the gaucho in Martin Fierro designated a unique Argentine national spirit forever out of reach of the new immigrant populations that had entered the country in the late $\mathrm{I} 800 \mathrm{~s}$ and the early I900s. A reading of Martin Fierro sees the epic poem in the context of those later readings that exploited the poem's xenophobic and anti-cosmopolitan turns (Sommer, I989, pp. I22-I 23). As a result, the gaucho, and specifically his portrayal in Martín Fierro, came to represent the early beginnings of a literary tradition positioned against immigrant workers, who, by the I920s, populated most, if not all, industries and service sectors of the economy, from agricultural labor, to semiindustrialized industries such as meatpacking, as well as servicework and white-collar office work in Buenos Aires. ${ }^{9}$ In contrast to the toiling marginalized masses in agriculture, industry, and service, nationalist ideologues idealized the gaucho's free-roaming in the Argentine plains.

Against this background, the I920s saw the emergence of two literary groups: the Florida group and the Boedo group. Each group traced its lineage back to one side forged in the early I90os between the mythical gauchos of the past and the immigrant masses crowding cities such as Buenos Aires. The Florida group took its name after the main shopping and business street in Buenos Aires and its members held in high regard the work of Argentine intellectual and poet Leopold Lugones (I874-1938). In particular, Lugones's nationalist reading of Martín Fierro had a powerful impact on the writers associated with the Florida group, one of whose publications was named Martín Fierro. Contributors to the Florida group and the journal Martin Fierro were thus often referred to as 'the martinfierristas,' including well-known Argentine author Jorge Luis Borges. ${ }^{\text {IO }}$ In contrast, the Boedo group took its name after the Boedo neighborhood, the main working-class district in Buenos Aires at the time. The Boedo group was connected to the Claridad publishing house and the Claridad journal. Antonio Zamora, an immigrant of Spanish origin, edited the 
journal and ran the publishing house, drawing the name Claridad from the French socialist Henri Barbusse's Clarté. The Boedo writers were of immigrant origin, mostly second-generation working-class writers whose parents had arrived in Argentina with the great wave of immigration in the late 1800 s and the early I900s. Writers associated with the group include Elías Castelnuovo, Leónidas Barletta, Álvaro Yunque, Roberto Mariani, César Tiempo, Aristóbulo Echegaray, Enrique González Tuñón, Raúl González Tuñón, Roberto Arlt, and many others. From its earliest conception, therefore, working-class literature in Argentina is intertwined with debates on immigration and immigrant culture.

The Boedo-group thus marks the beginning of a working-class literary tradition in Argentina. Not only were the writers associated with the group of working-class and immigrant backgrounds, but they also identified themselves as hailing from such backgrounds and claimed to write on behalf of the proletarian masses. The Boedo-writers saw themselves as forming a part of the working-class struggle. They also positioned themselves against the Florida-writers, who represent, in this instance, the bourgeois national literary tradition of the local elites inaccessible by the immigrant masses. ${ }^{\text {II }}$

International events, such as the Russian Revolution of I9I7 and developments within the Soviet Union, inspired the Boedowriters. However, in practice, they were quite isolated, seeking inspiration in writers who were not necessarily those who commanded most influence on proletarian literature elsewhere. For example, they sought inspiration in authors such as Russian realists Fyodor Dostoevsky and Leo Tolstoy, as well as in specific texts by the Russian philosopher and Marxist Georgi Plekhanov and French philosopher and poet Jean-Marie Guyau (Castelnuovo, I935). In a more local context, the Boedo-writers also looked to realist writer Manuel Gálvez (I 882-I962) and his novels about the working poor of Buenos Aires. ${ }^{\mathrm{I2}}$ Gálvez is an important precursor in his focus on the working-class in more favorable terms than did the naturalist authors of the late I9th century, whose literature is profoundly reactionary, responding to the financial crisis of the I 88 os with misogynist, racist, anti-semitic, and anti-immigrant tracks. ${ }^{13}$ Gálvez, however, still approached the working class in 
the manner of the gentleman writer who visits the slums and researches the subject matter for his books. In contrast, the Boedo writers positioned themselves as writing from the slums. As such, the contributions of the Boedo-writers to Argentine literature has received more negative treatment than that of the Florida-group, and critics have claimed their works to be more didactic and concerned with truth-telling than artistic creation (Montaldo, 2006, pp. 329-330). However, recent work on the I920s and the 30 s has reconsidered this assessment, and there is increased interest in the period amongst literary critics. ${ }^{14}$

The boundaries of the Boedo group are porous, and as Leonardo Candiano and Lucas Peralta point out, there are certain limits to understanding Boedo-literature as standing in for the tradition of militant working-class literature. Candiano and Peralta work with a narrow definition of the group, limiting the core members to only those who published novels in a particular series by Claridad. They resist the broader definition of 'boedismo' that critics worked with throughout the 2 oth century in tandem with terms such as social literature and the social novel. Instead, they propose to restrict the Boedo designation to a narrow body of works while recognizing the broader implications that these works have had on politically committed and militant realism in Argentine literary history (Candiano \& Peralta, 2007). I am in agreement with Candiano and Peralta's resistance to using a broad definition of 'boedismo' to stand in for anything connected to a literature of the left, the social novel, proletarian literature, and even the broader tradition of working-class literature. Throughout this essay, while the Boedo-school is understood as forming a part of the proletarian moment of the I920s and the $30 \mathrm{~s}$, the focus is on the militant realism that members of the Boedo group and fellow travelers practiced in their writing, and how this realism was folded into the national literary history of Argentina. Although the past two decades have seen increased interest in the cultural production of the I920s and the 30 , there is yet to be a discussion of the precise origin of the conventional critical narrative that posits Argentine proletarian literature as unique in its use of naturalist and grotesque aesthetics. This understanding of Argentine workingclass literature as pathological in its obsession with stories of 
social terror, grotesque portrayals of marginal subjects, and the naturalist imaginary, continues to shape not only Argentine literary criticism, but also Argentine literature.

The best rendition of how working-class literature has been understood as pathological in its naturalist and grotesque account of proletarian misery appears in a short story by Argentine writer Oswaldo Lamborghini (I940-I985), who satirizes this aspect of Argentine working-class literature. Lamborghini was an iconic poet of the new left in Argentina, a bohemian writer associated with the avant-garde journal Literal (I973-77), a journal influenced by Lacanian psychoanalysis and leftist politics. The third part of Lamborghini's 1973 novel or long prose poem Sebregondi retrocede [Sebregondi Retrenches] includes a short story titled "El niño proletario" [The Proletarian Boy] (Lamborghini, 2003). In this story, three bourgeois boys brutally rape, torture, and kill a poor working-class newspaper boy. One of the assailants narrates the story and congratulates himself for escaping the fate of being born into a proletarian household. "El niño proletario" is notorious for its detailed and lurid descriptions of the violence endured by the boy, its gore and grotesque aesthetics, and, finally, for its satirizing of Argentine proletarian literature. The narrative exaggerates the violence against the defenseless proletarian boy to such an absurd degree that the violence is almost humorous in its depiction. As an example of just how excessive the narrative is, one can cite the apologetic introduction to the English translation of the story that the editor of the journal that published the translation found necessary to include with the text: "It is a disgusting story, and I don't like it. [...] So, be forewarned, and read at your own risk" (Lamborghini, I995, p. 75).

It may indeed be difficult to understand how a short story graphically depicting the rape and torture of a proletarian boy forms a part of Argentine working-class literature. The story offers no hope for salvation nor any hint of a collective struggle, nor does it seek to document or register working-class life as anything more than a horrid suffering of cruelty at the hands of the bourgeois class. However, as the story harkens back to the critical account that posits the Argentine social novel as nothing but tales of social terror, Lamborghini’s “El niño proletario" turns out to be central 
to the argument developed here. Lamborghini's short story captures well the social terror critics have analyzed as the distinguishing characteristic of the literature produced by the Boedo group and, in particular, of the author who is most readily associated with the group and the broader tradition of working-class literature in Argentina. The author in question is Elías Castelnuovo (1893-I982), whose role within Argentine literary history has been quite important despite the widespread dislike for his literature amongst critics.

The account that best presents the ambivalent place of Castelnuovo in Argentine literary criticism is Beatriz Sarlo's treatment of his work in Una modernidad periférica: Buenos Aires I920 y I930 [A Peripheral Modernity: Buenos Aires 1920-1930] (1988). Sarlo (I942-). Sarlo, who is an influential literary critic and scholar in Argentina and beyond, devotes a section to Castelnuovo's work, which she reads with amusement while analyzing his naturalist tendencies. Sarlo points out how Castelnuovo's writing is infused with "the hyper-naturalism of medical manuals," and thus "more than realist fiction, he writes 'scientific fictions' of social terror"' (I988, p. 20I). Where the realist narrator would pause, according to Sarlo, Castelnuovo continues his narratives, writing detailed descriptions of suffering and gore. Sarlo's account of the social terror that permeates the literature of Castelnuovo is widely cited and serves as a pivotal moment within the reception history of not only Castelnuovo but also that of the Boedogroup (Astutti, 2002, pp. 430-438; Rodríguez Pérsico, 2013, p. I 5; Saítta, 2008, pp. I09-I I0).

Routinely, critics have characterized Argentine proletarian literature as hyper-naturalist and grotesque with Castelnuovo serving as the best representative for this literature. While Sarlo's I988 Una modernidad periférica is the source that is most often cited for this reading, a similar account is found in Juan Carlos Portantiero's I96I study on realism in Argentine literature as well as Lamborghini's short story "El niño proletario." Thus, the same critical narrative informs Sarlo's reading and Lamborghini's "El niño proletario," which in turn demonstrates how institutionalized this understanding of Argentine proletarian literature is. Indeed, Lamborghini cites Castelnuovo as his inspiration for the 
notorious "El niño proletario," acknowledging how the story was inspired by the Boedo literature and in particular by Castelnuovo's Vidas Proletarias: Escenas de la lucha obrera [Proletarian Lives: Scenes from the Working-Class Struggle] from I934 (Rubione, I980). However, as Adriana Rodríguez Pérsico points out, other works by Castelnuovo better match "El niño proletario" (2013, pp. 70-7I). In fact, Vidas Proletarias is one of the few works by Castelnuovo that evade the social terror that otherwise characterizes his work. This complicates the account offered by Lamborghini and suggests the source for his inspiration for "El niño proletario" is not necessarily Castelnuovo's work, as much as it is a particular interpretation of his oeuvre. Compared to Lamborghini and even the earlier short story by Echeverría, Castelnuovo emerges as almost tepid in his social terror.

The extreme pessimism of many of Castelnuevo's stories produced during his Boedo phase is puzzling for anyone looking for classic proletarian tales inspired by the Russian Revolution of I9I7. Instead of strikes and red flags, the reader confronts dead bodies, a fetus left to die a slow death in a blood puddle, orphans and children left alone and miserable in the world, and so on. As in Lamborghini's story, where the raped, tortured and lifeless body of the proletarian boy is left behind on a garbage heap, the early narratives of Castelnuovo offer nothing but pathological suffering and no hope for individual salvation, let alone hope for the collective struggle of the working class. Lamborghini's citation of Castelnuovo as an inspiration for "El niño proletario" indicates how persistent this view of Castelnuovo is and how infused with this author the discussion of proletarian and working-class literature in Argentina is. And yet, it is worthwhile revisiting this characterization of Castelnuovo's literary oeuvre as well as how his work has been made to designate the broader tendencies of the Boedo-group, especially since this reductive understanding of Boedo has come to generally stand in for the "social novel." In other words, what should be understood as a contribution to proletarian literature and, by extension, working-class literature, has come to represent the two in its entirety. Before any meaningful examination of working-class literature in Argentina is to take place, it is necessary to reconsider this account. On the one hand, 
it is necessary to reconsider the account that posits Castelnuovo only as a writer of social terror and pathological suffering, while, on the other hand, it is crucial to resist portraying Castelnuovo as the most important representative for committed literature within Argentine letters.

\section{Elías Castelnuovo, the Proletarian Poet}

Elías Castelnuovo (I 893-I982) is not only known for his life-long commitment to the left but also his ability to adapt to political changes. Castelnuovo may be said to bridge the old communist left of the I930s and the new left of the I960s since his political development includes his early formation as an anarchist in the I9Ios, the turn to communism in the early I930s, his sympathy for Peronism in the mid-I940s as well as liberation theology and third worldism of the new left in the I960s and 70s (Eipper, I995, pp. I4-I 5; Tarcus, 2007, pp. I 27-I 28). He is best known for his work from the I920s and 30 s and is often referred to as "the Argentine Gorky" (Barcos, 2003, p. 9; Eipper, I995, p. I I; Portantiero, I96I, p. I20; Tarcus, 2007, p. I27). This designation stems from his call for writers to contribute to the development of proletarian literature in Argentina. For example, in I934, he lamented the fact that proletarian literature had not surfaced in Argentina, claiming the genre to be underdeveloped compared to other nations.

Castelnuovo is, without doubt, the most important voice in calling for the writing of proletarian literature in I920s and 305 Argentina. During these years in Argentina, as elsewhere, the plans for this movement were quite ambitious. The Union of Proletarian writers called on writers and workers to write proletarian literature on the pages of Actualidad, a communist cultural journal that Castelnuovo edited between I932-36, and the first and only issue of Ahora!, a cultural journal published in Santa Fe, included an announcement asking for the support of at least 300 workers as well as submissions for the journal ("La unión de escritores proletarios," I932, p. 46; "Resoluciones," I932, p. 2).

At the center of proletarianism in Argentine literature, we find Castelnuovo. Not only was he the editor of Actualidad, but he also founded, along with the better-known Argentine novelist 
Roberto Arlt ( 1900 - I942), the Union of Proletarian Writers in I932. In its first announcement, the union declared its intent to participate in the class struggle, to combat imperialism, and to defend socialism in the Soviet Union ("De la unión de escritores proletarios," I932, pp. 45-46; "Unión de escritores proletarios," I932, pp. 45-46). Around this time, Castelnuovo had published the first of two travel narratives based on his trip to the Soviet Union in I93 I. By the time of his visit, Castelnuovo was already an established author who, in I924, had won a literary prize for his first short story collection, Tinieblas [Darkness] (I923). During the period between I923-I93 I and before traveling to the USSR, Castelnuovo published collections of short stories fitting Sarlo's description of them as tales of social terror. After his return from the Soviet Union in I93 I, however, Castelnuovo begins to carve out a new intellectual position for himself, creating a distance between his early anarchist affiliation and his newly adopted communism (Saítta, 2008, p. I03). The early narratives are characterized by the social terror that Sarlo identifies in Castelnuovo's work and, as Adriana Astutti points out, in these stories: "The poor are always in a marginalized position, held captive by their circumstances," and thus are never portrayed as agents of "resistance" (2002, pp. 437-438). Back in Argentina, he publicly embraces communism and describes his transformation in a series of short articles in Bandera Roja, a journal published by the Argentine Communist Party (Saítta, 2008, pp. 99-I07). Furthermore, the literature he writes in the 3 os sees the introduction of workers and political agitators. The marginalized outcasts and the lumpen-proletarians of his early works are now accompanied by workers and communists engaged in a collective struggle.

Indeed, critics have noted the changes in Castelnuovo's politics and persona after his return from the Soviet Union. And yet, this has not altered the assessment of his literature as failing to move beyond the anarchist naturalism of his early works. Nor has it revised the equivalency describing his literature and that of the Boedo-school, or, for that matter, the characterization of Castelnuovo/Boedo as encompassing little more than tales of social terror. Finally, this assessment is still the prevailing paradigm within which politically committed working-class literature 
is discussed and is the yardstick used to measure and categorize other writers and works. For example, in the recent revival of the Boedo writer Roberto Mariani (I893-I946), critics have found it challenging to connect the realism of Cuentos de la oficina [Stories from the Office] (I925), with the characterization of the Boedo literature as naturalist tales of social terror. Mariani's Cuentos de la oficina includes a ballad in which the office is personified as an all-embracing live-giving mother, who speaks to the office-worker reminding him of her role - the office's - in sustaining his life. The ballad is followed by sketches depicting the work of different employees within a large British department store and closes with a short play in which children of different classes play a game demonstrating how an upper-class child cannot understand the social experiences of poor children. The game is an allegory treating the divide between the Florida and the Boedo groups. As a whole, the work resembles the collective narratives that the proletarian literary left of the interwar period developed in other national contexts. ${ }^{\text {Is }}$ Each sketch, poem, or play, can stand on its own. Collectively, though, they build a picture of proletarianized - indeed precarious - white-collar labor. In Cuentos de la oficina, Mariani makes explicit the connection between white-collar office workers and the unemployed Buenos Aires' lumpen proletariat. This focus on proletarianized employees and the salaried masses is not unique amongst writers in Buenos Aires at the time, nor when considered in relation to the international dimensions of the proletarian centered left. ${ }^{\mathrm{I}}$

Mariani's realism does not engage with the social terror that characterizes Castelnuovo's early work. Instead, the reader is confronted with tense sketches portraying the psychological and physical exploitation of labor within the office as well as that of the unemployed office worker. The office appears as a monstrous entity demanding long hours and sacrifice of its workers while preventing any form of unionizing or collective struggles. Or, as the office seductively proclaims in her motherly ode to the free subject roaming the streets of Buenos Aires: "No one dies from working eight hours a day [...] I only require eight hours from you. And I pay you; I clothe you; I feed you. You don't have to thank me! This is how I am" (Mariani, 2008, p. I30). ${ }^{17}$ Although 
Mariani was a Boedo writer who actively rallied in his writing against the Florida group (Mariani, I92 I, pp. x-xi, I924), recent criticism of his work has seen him "salvaged" from the proletarian centered literary left (or Boedo). His recuperation hinges on pitting his work against that of Boedo writers such as Leónidas Barletta and Castelnuovo, who have come to represent a more dogmatic realist tradition.

In contrast, Mariani's work is recognized for its "subjective realism," which is also said to characterize the work of Argentine writer Roberto Arlt (Carbone \& Ojeda Bär, 2008, p. 44). Arlt is an important figure within Argentine and Latin American literature, an author whose realism is routinely hailed for its portrayal of the urban landscape of Buenos Aires, the lumpenized existence of petit-bourgeois white-collar labor, its treatment of finance, and the dystopian enterprise of fascism in the I920s and the $305 .{ }^{18}$ By most accounts, Arlt does not fit within a landscape characterized by the Florida and the Boedo groups. Instead, he emerges as an individualistic author who evaded all forms of categorization. He is understood to be neither of the avant-garde circles nor the socially committed literary circles around the Boedo group. For example, Rocco Carbone and Ana Ojeda Bär define the work of Arlt and Mariani as belonging somewhere in between the aesthetics of the Florida and the Boedo groups. They link their realism to immigration, claiming that this in-between-space is "a textual space whose general and binding characteristic is its aesthetic representation of immigration" (2008, pp. 6; 9; 1 5-16). This characterization hinges on pitting Arlt and Mariani's realism against that of Castelnuovo, whose work Carbone describes as dogmatic while claiming Arlt's work to be more open and rhizomatic (2007, pp. IIO-III). ${ }^{19}$

It is beyond the scope of this discussion here to treat in detail the complicated reception history of Roberto Arlt (Drucaroff, I998; Saítta, 2000). However, it must be noted that the recuperation of Mariani's work hinges on this history and is premised upon the similarity between the realism of Arlt's major novels and Mariani's Cuentos de la oficina. As Mariani's literary output does not fit within the given categories, i.e., the account that reduces politically committed literature to Boedo and then Boedo to 
Castelnuovo's tales of social terror, Mariani's work must be relegated to an alternate category. As should be clear, then, Castelnuovo is still quite central in recent discussions as it is this author whose work determines other writers' classification and whether or not they belong to categories such as "committed literature," "proletarian literature," or even the broader category of "working-class literature." Thus, it is worth pursuing the precise origin of the critical narrative that reduces Argentine working-class literature to the Boedo-group alone, and more importantly, to Castelnuovo's early works. As it turns out, the analysis credited to Sarlo can be traced directly back to Elías Castelnuovo himself. For all the dislike that critics have for his work, Castelnuovo as the arbiter for whom belongs to the tradition of militant working-class literature is still quite significant within contemporary Argentine literary studies.

The short-comings of Castelnuovo's political and aesthetic model for the committed writer during his Boedo-phase, or in his early pre-USSR period, are easy to identify. If the working-class masses are nothing but suffering beasts of forces beyond their control, the revolution becomes impossible. Moreover, Castelnuovo himself identifies this element of his early works as problematic in his writing from the I930s, a decade in which he develops his critique of this stance in various places. For example, a version of this self-critique is found in his travel narrative, Yo ví... En Rusia! [I Saw ... In Russia! ] (I93 I), where he includes a peculiar dialogue between himself and Spanish-speaking Russians who criticize his literary work (Castelnuovo, I932, p. 58). This dialogue is semi-fictional as all of Castelnuovo's notes from the trip were confiscated by border control upon his return from USSR, resulting in him writing the travel narratives from memory. Moreover, it is highly unlikely Castelnuovo's work circulated beyond the Argentine border to the Soviet Union during this period. And yet, the dialogue serves the purpose of elaborating Castelnuovo's self-criticism that emerges in his writing after his trip to the USSR.

An even better example is found in the introduction to Vidas Proletarias published in I934. In a thinly veiled self-critique, Castelnuovo puts forth an analysis of social literature in Argentina. Although Castelnuovo speaks of 'social literature' in general, his 
work from the I920s best matches his descriptions. He focuses on the limits of anarchist politics from the standpoint of his newly acquired communism, thus echoing his writing in Bandera Roja and the travel narratives, and presents a critique of his earlier understanding of revolutionary politics and art. He readily acknowledges how the revolution had been impossible within his earlier model for committed politics and art since:

The working class was presented, sentimentally, as the class that suffered the most. The image of a crucified Christ, sucking vinegar and bleeding from all the nails, served ordinarily as a model. This is why writers chose to study the lumpenproletariat - traitors, beggars, prostitutes, neuropaths, assassins - and not the healthy and active proletarian masses and the peasantry. [...] However, the mistake lay not in depicting suffering, but that suffering was converted into an end in itself. (Castelnuovo, I934, pp. I I-I 2)

According to Castelnuovo, social literature in early I 920 Buenos Aires was characterized by "an undeniable love for the dispossessed masses" while simultaneously languishing under the morbid influence of metaphysics, pessimism, and pathology. This literature portrayed the working class as defeated without identifying the revolutionary potential of the working class or explain the material basis for their suffering (1934, pp. 7-8).

In this context, Castelnuovo's fictional work from the I930s must be understood as his way of adopting a new set of political and aesthetic parameters for his literature that will meet the standards of his faith in the historical mission of the proletariat. However, almost as if signaling the difficulty of this move, Castelnuovo only publishes two fictional works during the r930s. He groups together three short plays in Vidas Proletarias ( 1934) and publishes a short novella titled Resurrección: Impresiones de una conciencia libre sobre la epopeya heroica del pueblo español [Resurrection: Impressions of a Free Consciousness about the Heroic Struggles of the Spanish People] (1936-7). Critics frequently comment on the former, but Resurrección has not received any critical attention. ${ }^{20}$ In Vidas Proletarias, the suffering of the marginal subject is replaced with the collaboration between workers, the lumpen, the abject, the unemployed, and communist agitators in a protest march and a strike. Even though both plays end with negative setbacks for the struggle, both include the "tragic optimism" common 
in proletarian literature of the period (Bivens, 20I 5, p. 239). The tragic optimism of Vidas Proletarias is taken to a new level in Castelnuovo's Popular Front novella, Resurrection from around I936-7, where his euphoria for the Popular Front displaces his earlier pessimism. The novel curiously inverts the usual scenario of subjects gaining class-consciousness and presents the reader with a former soldier, already class-conscious, who is confined to a wheelchair and unable to join the struggle against the fascists in Spain. Instead, all he can do is listen to radio broadcasts of the struggle. His transformation, then, involves the miraculous return of his physical health, when he, at the most pessimistic moment in the story, wakes up from a nightmare in which he foresees the victory of the fascists and the death of his comrades. He joins the revolutionary brigades, and the novel closes with him marching towards Madrid along with other fighters: "Madrid will be the tomb of fascism! [...] They cannot win. They will not win! They will never win!" (Castelnuovo, I936, p. 75).

Critics have not commented on Resurrection, nor does it figure in Sarlo's analysis of Castelnuovo's failure to overcome the anarcho-naturalist materialism characterized in his early works. Despite the overwhelming consensus that Castelnuovo's realism borders on naturalism, critics still use his early work as the example of committed literature in Argentina. The work Castelnuovo rejected as a model for committed communist literature is the example that critics use for committed literature, whether understood as solely that of the Boedo group or in the broader context of working-class literature. No other phrase summarizes better the reception history of Castelnuovo's work than Sarlo's account of his writing as "'scientific fictions' of social terror" (I988, p. 20I). This characterization echoes earlier assessment of his work while also serving as the norm against which all other committed, social, or proletarian fiction is measured. However, in the early i 960 , Juan Carlos Portantiero discusses the social terror of Castelnuovo's literature, citing the introduction to Vidas Proletarias while warning against the danger of reducing the work of the Boedo group to only Castelnuovo's writing (I96I, p. I28). Despite Portantiero's warning, critics continue to do so, measuring all other forms of committed literature against the Castelnuovoian earlier tales of social terror. By doing so, critics 
follow Castelnuovo's own example of routinely positioning himself as being personally representative of something greater than himself. One revealing example appears in his travel narrative, $Y_{O}$ ví... En Rusia!. In this discussion, Castelnuovo relates how his flatmate urges him to pose for a painting titled “The Last Supper of the Apostles" ("La Ultima Cena de los Apóstoles"), whose theme is the worldwide revolution. The work, as Castelnuovo describes it, is a collage that besides including "the shadow of Lenin presiding over the banquet" comprises a collection of people of different ethnicities, including "the head of a Negro from Sumatra," "a Chinese from Kuangsí," "a German," “a Turk,” and so on, while of course including Castelnuovo's portrait as the Latin American specimen (I932, pp. I4I-I42). The episode demonstrates how Castelnuovo was not afraid of taking a seat at the revolutionary table under the shadow of Lenin and among other nationals, thus embracing his role as the Latin American representative for the working-class struggle and its literature.

Castelnuovo's centrality in discussions of proletarian literature and committed aesthetics in Argentine letters obscures the breadth of proletarian literature in Argentina and elsewhere. This account overlooks how proletarian and working-class literature(s) are situated in a peculiar space between bourgeois art forms and militant modes of expression that more often than not set out to destroy that bourgeois tradition. Furthermore, although Argentine proletarian writers were quite isolated in practice, they were also under the influence of international currents and looked towards the then newly founded Soviet Union for inspiration. While it is important to recognize the isolation of Argentine anarchists, communists, and leftists during the interwar period, it is equally important to see the local development of proletarian literature and politics in the context of transnational developments. When treating Argentine proletarian literature in this context, it is crucial to understand Castelnuovo as a member of the movement for such literature and avoid reducing proletarian literature (or the Boedo-group) to his work alone, let alone only his early works. Nor can the broader discussion of working-class literature rely on such a reductive understanding of not only proletarian literature 
but also the Boedo-school. If the task is to begin a discussion of the tradition of working-class literature in Argentina, then Castelnuovo must cease to dictate the terms of that discussion.

Finally, it is important to reconsider the social terror characterizing Argentine literature in general and understand its influence on writers such as Castelnuovo, who neither initiated this tradition nor offers the best example of its excesses. For example, one could easily trace the grotesque and vicious violence in Lamborghini's "El niño proletario" back to Echeverría's El matadero, thus acknowledging how both stories index moments of brutality within Argentine history. Not long after Lamborghini published "El niño proletario," the military junta took power on behalf of the local bourgeoisie. In place of the barbaric and lowerclass masses of El matadero, three bourgeois boys rape and torture a proletarian boy. The bourgeois boys know no limits and see the proletarian masses as a body to be terrorized and destroyed. That Lamborghini misidentifies the source for "El niño proletario" as Castelnuovo's Vidas Proletarias reveals how the critical account of Castelnuovo and proletarian literature as tales of social terror is the main influence here. Once local categories such as Boedo and 'social novel' are contextualized with reference to broader and more transnational categories, one can begin to appreciate the breadth of Argentine proletarian realism and working-class literature, which includes, amongst many others: Castelnuovo, Arlt, and Mariani.

\section{In the Shadow of the Social Novel}

It is difficult to do away with longstanding critical narratives and their legacies, especially when Argentina's brutal history shapes such narratives. And yet, it is necessary to distance the discussion of Argentine working-class literature from the narrative molded throughout the 20 th century, i.e., the critical account that reduces proletarian and working-class literature to the Boedo group, and then the Boedo group to Castelnuovo's work alone. Without such distancing, it is difficult - if not impossible - to find proletarian and working-class literature worthy of discussion within Argentine letters. Many authors whose work engages with the 
working class and the political struggles associated with classbased politics would fall outside the scope of the categories based on this account. For example, Roberto Mariani and Roberto Arlt, whose work simply does not fit within the given categories, falls outside the corpus of working-class literature, even though both authors were quite concerned with labor, labor-conditions, and the laborer in their writings, and, more importantly, both saw themselves as forming a part of the working-class struggle. Another example of a writer not associated with the Boedo group whose work should be understood as forming a part of a workingclass literary tradition within Argentine letters is Josefina Marpons, whose treatment of the lives of working-class women in the early decades of the 2oth century in Buenos Aires is central in her novel 44 horas semanales [44 Hours a Week] (I936). ${ }^{21}$

And yet, it is important to recognize how local and historical developments shape longstanding critical narratives and the literature they deal with. In I934, Castelnuovo complained about proletarian literature's underdevelopment in Argentina, blaming it on the uneven development of the Argentine economy and the nation-state in the early 20 th century (1934, p. 5). During this time, Argentina was surely peripheral, not only in terms of what were then the shifting centers of capital accumulation worldwidefrom Britain and to the USA-but also in relation to the then newly formed Soviet Union. However, during this period, Buenos Aires was also an outpost for British-led imperialist capitalism in the Latin American region, and as such, possessed a semi-hegemonic place within the world-system of capital accumulation. Thus, Castelnuovo and the other proletarian writers of the 20 s and the 3 os were caught between extreme contradictions. They moved within a society that comprised of a largely immigrant workingclass, many of whose members did not possess reading skills. No less important was the emerging petit-bourgeois middle classes holding white-collar office posts related to the administration of British interests in the Latin American region as well as in retail and business associated with the luxury consumption of the local elite (Bergero, 2008; Rama, I996). This context helps explain why a majority of the writers associated with the Boedo group worked in administrative jobs and not in factory production, such as the meatpacking industry. 
Thus, what often seems to be a peculiarity of Argentine proletarian and working-class literature, i.e., its focus on office workers and the lumpenproletariat as opposed to factory workers, can be explained by referencing the composition of the working class in Argentina at the time. Marcos Del Cogliano cites Portantiero's I96I study on Argentine realism, claiming that proletarian literature in Argentina was impossible for the simple fact that the country did not have a fully formed working class (2019, p. I06). However, this condition was not particular to Argentina. For example, part of the debates surrounding the proletarian movement concerned the question of whether the movement would have to wait for the proletarian class to develop in order for the revolution to materialize. In regard to the particular case of the Argentine economy and political history, one would have to recognize how the consumerist factory worker only emerged with Peronism in the I940s and the 5os and how this figure and the corresponding political ideology of Peronism accompanied industrial development. Peronism corresponds, roughly, with the compromise reached between labor and capital in other national contexts, with labor-unions winning some gains provided by the post-war stability of capital accumulation. However, in Argentina, the working class never assumed the semi-hegemonic place, as was the case in countries where the tradition of working-class literature became united with the official national literature, such as in the Nordic countries.

More importantly, the historical development of a repressive state apparatus with frequent coups, including the brutal repression of the new left in I976, is a context that has to be reckoned with and helps explain the reasons why working-class literature never gained a secure place within Argentine letters. The social terror that characterizes Argentine history seeps into its literature in quite transparent ways, thus, making Argentine literature quite specific in its brutality. From El matadero and to "El niño proletario," through Castelnuovo's work, there is a direct line, including other works such as Rodolfo Walsh's Operation Massacre [Operación masacre] (I957). Walsh's book is an early precursor to the testimonial novel of the I960s through the I980s, which as Eugenio Di Stefano points out "can also be understood as a return to the proletarian literature of the I930s, defining itself as a realist 
style that seeks to document and capture reality of subalterns" (2017, p. I39). The testimonial novel, however, no longer focuses on labor or workers, as Di Stefano notes, and, one can add, no longer is this literature aligned with a working-class movement specifically. Instead, the testimonial turn, in Argentina and elsewhere in Latin America, is rooted in the new leftist moment of the I960s and the 70s. This moment in Argentina was brutally repressed in 1976 , and thus the testimonial turn, or literature and literary criticism bearing witness to the atrocities of the Dirty War, was prevalent through the I990s and into the 2000s. The field of memory studies is understandably quite large within Argentine letters and has been more concerned with unearthing the lives of those who lived through the terror of the Dirty War than with the political projects that the Dirty War put an end to (Bosteels, 20 I 2, pp. 20-2I).

With the full integration of Argentina - along with the Latin American region - into the world system of capital accumulation, contemporary Argentine literature demonstrates similar tendencies as contemporary literature elsewhere. Here we find increased attention to precarious and deteriorating labor conditions, an emphasis on part-time work, and the demolition of the protections that earlier labor-laws provided. The crisis of neoliberalism arrived early in Argentina with the $200 \mathrm{I}$ crash of the stock-market that proved the utter failure of the neoliberal project to provide stability for the Argentine economy. It is always difficult to survey the present. However, as Alejandra Laera and Fermín Rodriguez point out in a special issue devoted to the laboring body within contemporary Latin American literature, one can discern a turn towards documenting (2019, p. 33). For example, in Alta Rotación. El trabajo precario de los jóvenes [High Rotation: The Precarious Work of Young People], Laura Meradi fictionalizes her own experience of working various low-paid part-time jobs in Buenos Aires. According to Martín De Mauro Rucovsky, Meradi crosses the line between journalism and fiction, producing a "hybrid genre between journalism and literature or a type of journalism with literary pretensions" (20I9, p. I4I).

In the Argentine working-class literature historiography, it is notable how recent works, such as Meradi's novel as well as 
Laera's and Rodriguez's special issue on the laboring body, represent a return to the investigative manners of naturalist writers such as French author Émile Zola and American novelist Jack London. In short, a resurgence of naturalist aesthetics characterizes the recent turn towards new forms of labor within contemporary literary studies and literature. In a similar manner as London, who for The People of the Abyss (1903) went undercover to study the misery of the London poor, Meradi gathered her materials for Alta Rotación while working undercover in various low-paid jobs in Buenos Aires. Meanwhile, Laera and Rodriguez's approach also documents new forms of labor and exploitation in contemporary Latin American literature. This is quite different from the approach of proletarian writers who were all engaged with the political struggle of the working class and aimed to produce a new subject position whose identity could shoulder the burden of representing the revolutionary subject. This project required a new form of realism not necessarily focused on documenting labor and the lives of the laborer but emphasized the new forms of consciousness and agency required for the struggle to come. This is the project that Elías Castelnuovo engaged with after he distanced his work from the early anarchist-naturalist approach centered on documenting in lurid detail the grotesque lives of unemployed and semi-employed lumpen-proletarians in Buenos Aires of the I9Ios and the 20s, or during the I930s when he writes Vidas Proletarias and Resurrección.

The renewed interest in the working-class experience in contemporary Argentine literature and literary studies is to be celebrated. However, it is equally important to reexamine working-class and labor literature of the past and to afford this tradition the attention to detail it deserves. Although national literary history needs to be contextualized by local historical developments, it is as important to view this history in light of developments elsewhere, thus, avoiding claims positing proletarian and working-class literature as unique in its emphasis on social groups that are defined by elements other than industrial factory work. As in much of the world, industrialization was not a dominant theme in Argentine literature of the first half of the $20^{\text {th }}$ century. ${ }^{22}$ Instead, - and as elsewhere - this literature is focused on immigration, agriculture, 
and the emerging petit-bourgeoisie or the salaried masses. Hence, much of the literature devoted to the working class focuses on the making of the working class and the massive social and economic transformations that were necessary for this class to emerge. To conclude, this essay does not pretend to offer a comprehensive view of Argentine working-class literature. Instead, the aim of this discussion is to open up a starting point for such a discussion to take place, a point from which working-class literature can be examined in both its national specificity and in relation to international developments. In order for such discussion to take place within Argentine literary studies, it is crucial to reconsider the conventional narrative that posits Elías Castelnuovo as the best representative for I920s and 3 os literary radicalism.

\section{Endnotes}

I. As noted by Eugenio Di Stefano in his discussion of literature in Mexico, working-class literature is not a central category within Mexican literary studies (20I7, pp. I28-I29). The same can be said for Latin American studies in general. For example, the Andean region of Latin America, where indigenous populations form a high percentage of the population, literature devoted to the working class is characterized by concerns for the indigenous populations. Thus, this body of works is defined as indianismo, indigenismo, and neo-indigenismo, or with terms drawn from the word indigenous. Other examples of genres particular to the Latin American region include those devoted to the violent history of the region. Since Latin American history is filled with brutal dictatorships across the region, a major body of works is devoted to dictatorships forming specific genres while the aftermath of such epochs is characterized by testimonial literature. Finally, a large body of works is devoted to the exploitation of natural resources in the region, and while this literature is concerned with the exploitation of both indigenous and immigrant labor, it is not necessarily discussed in terms of working-class literature. Rather, the attention is on the exploitation of natural resources and labor.

2. Even during the interwar period, writers associated with the communist left and the Argentine Communist Party used the term 'social literature' in tandem with proletarian literature. For example, an early study on the period by Álvaro Yunque, who was a Boedo writer, 
was titled La literatura social en la Argentina [Social Literature in Argentina] (I94I). However, as Candiano and Peralta point out, the term 'social novel' is difficult to define as all literature is social in one form or another (2007, p. I 5). Furthermore, as Gramuglio notes, the term "proletarian literature" has been equated with social literature within Argentine letters (2002, p. 3I).

3. For a discussion of El matadero's role in Argentine literature, culture, and political discussion, see (Sorbille, 20I6, pp. I3-I9; 2I-24).

4. All translations of non-English quotations are my own. Here Gramuglio cites David Viñas's canonical account of El matadero as initiating modern Argentine literature. See (Viñas, I97I).

5. Perhaps most notably, writers such as Brazilian novelist Patrícia Galvão, Argentine writer Roberto Arlt, Mexican muralists such as Diego Rivera and David Alfaro Siqueiros, Peruvian poet César Vallejo, and many others, have been folded into the literary history of the avant-garde movements in Latin America.

6. Of course, plenty of excellent work exists on individual authors or particular national contexts. However, an attempt to map the proletarian literary left of the I920s and the 30 a across the Latin American region has yet to see the light of day. Comprehensive studies on proletarian literature such as Barbara Foley's Radical Representations (1993) and Michael Denning's The Cultural Front (I996) (2010) have yet to be undertaken in the context of Latin American literary studies.

7. Most of the immigrants came from Spain and Italy. Between I $857-$ I9I 6 about 4,7 million immigrants entered Argentina, of which 2,5 million settled permanently. Between I 889 and I905, around 200,000 immigrants entered every year, and from I905-I9I 2 that number grew to 300,000 . By I9I4 half the population was foreign-born (Rock, I975, pp. IO-I I; I4). Italians were by far the largest group of immigrants, totaling about $45 \%$ of the overall Argentine inflow, while Spaniards comprised about a third of the overall inflow. The great majority of Spanish immigrants settled in Argentina. Between I $857-$ I930 over 2 million Spaniards entered the country, and over half of them settled permanently (Moya, I998, pp. I-IO; 45-59).

8. The Argentine Socialist Party was founded in the mid-I89os and was led by Juan B. Justo. The party focused on liberal reforms 
and parliamentary politics. However, more successful among the working-class immigrant population were the anarchists. The period between I 890-I9I0 saw increased organizing amongst the working class led by the anarchists. Between 1902 and I9IO, the anarchists led massive general strikes in Buenos Aires, and when catholic church groups for workers and other such means of pacifying the public didn't work, the state turned to more direct repression. The antiimmigrant laws of the early 2oth century - the Law of Residence (I902) and the Law of Social Defense (I9IO) - came about in response to the general strikes of the early I900s (Rock, I975, pp. 80-82).

9. For an excellent introduction to the socio-economic and cultural landscape of Buenos Aires in the late I9th and early 2oth century, see (Bergero, 2008).

IO. It is beyond the scope of this essay to dwell on this topic in detail. However, it must be mentioned that working-class writers associated with the Boedo group were quite critical of the Florida group for its idealizing of the gaucho, which they saw as poised against immigrants. For an overview of this aspect of the Florida-Boedo debates, see (Candiano \& Peralta, 2007, pp. I8I-I90).

I I. Much ink has been spilled on the debates between Florida and Boedo. In general, the view is that both groups were less experimental than their colleagues in other countries. For example, John King claims that both sides of the conflict were more conservative in Argentina than elsewhere (King, I986, p. 28). See also (Gilman, 2006, p. 47; Montaldo, 2006, p. 328).

I 2. In the early 20 th century, the realist novel emerges most notably with authors such as Manuel Gálvez, whose novels are often viewed as important precursors to the Boedo aesthetic. Since Gálvez's novels deal with social issues such as prostitution and crimes in the slums, workers, and poverty, some even argue that the difference between Gálvez's work and that of Boedo is more sociological than literary or ideological (Bernini, 2003). As has been noted by critics, many of the authors associated with the Boedo group adored Gálvez, for instance, Lorenzo Stanchina and Nicolás Olivari. See (Olivari \& Stanchina, I924; Sarlo, I988, pp. I89-I9I; García Cedro, 2006, pp. Iо-I I; Astutti, 2002, pp. 425-426). A notable exception is the Argentine writer Roberto Arlt who wrote critical articles against the author (Arlt, I932). 
I3. At the turn of the century, the naturalist novel dominated the literary scene. Authors such as Julían Martel and Eugenio Cambaceres responded to the unfolding financial crisis of the 1890 s, which impacted the Argentine economy in significant ways, with novels such as La Bolsa [The Stock Exchange] (Julián Martel, I89I) and En la sangre [In Blood] (Eugenio Cambaceres, I 887). In these novels, Jews, women, and immigrants became the harbingers of destruction and were blamed for the failures of finance capital to provide sustained growth (Beckman, 20I3, pp. 86; I I9).

I4. The best examples of this reconsideration include the work undertaken by Candiano and Peralta on the Boedo group as well as the contributions of Sylvia Saítta, who has published extensively on the period in recent years.

I 5. As Barbara Foley points out in her study on proletarian literature in the USA: "Of the four modes of proletarian fiction, the collective novel is the only one that is primarily the product of I930s literary radicalism" (I993, p. 398).

I6. Mariani was not alone in focusing on the newly emerging salaried masses of Buenos Aires in the I920s and the early 3 os. For instance, Argentine writer Roberto Arlt (I900-I942) focused extensively on this class in his work. Alberto Pineta (I906-I97I) deals with this social class in Miseria de quinta edición: Cuentos de la ciudad (I928) while Josefina Marpons' 44 horas semanales (I936) focuses on female department store workers. In an international context, the focus on office workers and the emerging petit-bourgeois salaried masses was important to interwar Marxism and committed literature. For example, the emerging middle-classes are discussed in Georg Lukács's History and Class Consciousness (1923) and Siegfried Kracauer's The Salaried Masses: Duty and Distraction in Weimar Germany (1930). The class also plays an important role in the literature of the period, for instance, in John Dos Passos' U.S.A. trilogy (I930-I936).

I7. Lamentably, Mariani's work has not been translated into English. Difficult to translate in "Ballad of the office" is the tone assumed by the office, the upper-class manner of speaking to servants using the second person (you) as opposed to the more formal third person address used for formal encounters. Amongst the Boedo writes, Mariani's writing was unique in this regard as well as others 
(Candiano \& Peralta, 2007, pp. 230-23 I). For discussion on Marian's work in English, see (Leland, I986; Jordan, 2006).

I8. As a canonical author, the bibliography on Arlt is extensive. However, the most recent work on his fiction focuses on his work as an example of finance-literature or what often simply termed 'money-fiction' in Argentine literary studies. See (Laera, 20 4 4; Bollig, 20I7).

I9. Carbone and Ojeda Bär cite Carbone's study on Roberto Arlt and the grotesque (Carbone, 2007). However, it must be noted that the association between the grotesque aesthetics of the Boedo group, immigration and the new middle classes in Argentina, has formed a part of Argentine literary history since David Viñas's seminal account in (Viñas, I973).

20. John E. Eipper briefly mentions this book in his anthology of Castelnuovo's work. However, he does not include an excerpt from the novel (I995, pp. 25-26).

2I. For discussion of Marpons, see (Bergero, 2008, pp. I80-I82; Foster, I986, pp. I43-I49; Masiello, I992, pp. I83-I87).

22. For example, Volland points out how Chinese Proletarian and Working-Class fiction of the early $20^{\text {th }}$ century was more concerned with agricultural workers and peasants than the industrial workforce (2009, p. 99).

\section{References}

Arlt, R. (1932). “Manuel Gálvez asustado.” Actualidad, I (2), pp. Io-I I.

Astutti, A. (2002). "Elías Castelnuovo o las intenciones didácticas en la narrativa de Boedo.” In N. Jitrik \& M. T. Gramuglio, eds. Historia critica de la literatura Argentina, vol 6. El imperio realista. Buenos Aires, Emecé, pp. 4I7-445.

Barcos, J. R. (2003). "Prologue". In E. Casternuovo. Tinieblas. Buenos Aires, Librería Histórica, pp. 5-I4.

Beckman, E. (2013). Capital Fictions: The Literature of Latin America's Export Age. Minneapolis, U of Minnesota Press.

Bergero, A. J. (2008). Intersecting Tango. Cultural Geographies of Buenos Aires, 1900-I930. Pittsburgh, U of Pittsburgh Press. 
Bivens, H. (2015). Epic and Exile. Novels of the German Popular Front, I933-I945. Evanston, Northwestern U P.

Bollig, B. (20I7). "Theories of Money in Argentine Crime Fiction." Bulletin of Spanish Studies, 44 (3), pp. 505-525.

Bosteels, B. (2012). Marx and Freud in Latin America. Politics, Psychoanalysis, and Religion in Times of Terror. London, Verso.

Candiano, L. \& Peralta, L. (2007). Boedo, orígenes de una literatura militante: Historia del primer movimiento cultural de la izquierda argentina. Buenos Aires, Ediciones del CCC.

Carbone, R. (2007). Imperio de las obsesiones. Los Siete Locos de Roberto Arlt. Un grotexto. Bernal, Universidad Nacional de Quilmes Editorial.

Carbone, R. \& Ojeda Bär, A. (2008). "Con los botines de punta: La literatura de Roberto Mariani.” In R. Carbone \& A. Ojeda Bär, eds. Roberto Mariani. Obra completa I920-I930. Buenos Aires, El 8vo. loco Ediciones, pp. 5-57.

Castelnuovo, E. (1932). Yo ví...! ...En Rusía (Impresiones de un viaje a través de la tierra de los trabajadores). Buenos Aires, Actualidad.

Castelnuovo, E. (1934). Vidas proletarias. Escenas de la lucha obrera. Buenos Aires, Editorial Victoria.

Castelnuovo, E. (1935). El arte y las masas. Ensayos sobre una nueva teoría de la actividad estética. Buenos Aires, Claridad.

Castelnuovo, E. (1936). Resurrección. Impresiones de una conciencia libre sobre la epopeya heroica del pueblo español. Buenos Aires, Claridad.

Bernini, E. (2003). "Tinieblas, el libro extraño de Elías Castelnuovo: Estudio preliminar y cronología.” In E. Castelnuovo. Tinieblas. Buenos Aires, Librería Histórica.

De la unión de escritores proletarios. (1932). Actualidad, I (3), pp. $45-46$.

De Mauro Rucovsky, M. (20I9). "Rotar en la precariedad o sobre el trabajo de los jóvenes." A Contracorriente. Revista de Historia Social y Literatura en América Latina, I6 (3), pp. I39-160.

Del Cogliano, M. (2019). "Monstruos, galanes, sumisos: La disputa en torno a la representación visual del trabajador nacional." 
A Contracorriente. Revista de Historia Social y Literatura en América Latina, I6 (3), pp. 99-I 20.

Denning, M. (2010). The Cultural Front. The Laboring of American Culture in the Twentieth Century. London, Verso.

Di Stefano, E. (20I7). "Mexican Working-Class Literature, or The Work of Literature in Mexico." In M. Nilsson \& J. Lennon, eds. Working-Class Literature(s). Historical and International Perspectives. Stockholm, Stockholm U P, pp. I28-I 58.

Drucaroff, E. (1998). Roberto Arlt. Profeta del miedo. Buenos Aires, Carálogos Editora.

Eipper, J. E. (1995). Elias Castelnuovo. La revolución hecha palabra. Biografía, estudio crítico y antología selecta. Buenos Aires, Catari.

Foley, B. (I993). Radical Representations. Politics and Form in U.S. Proletarian Fiction, I929-I94I. Durham, Duke U P.

Foster, D. W. (1986). Social Realism in the Argentine Narrative. Chapel Hill, U of North Carolina P.

García Cedro, G. (2006). Boedo y Florida. Una antología crítica. Buenos Aires, Losada.

Gilman, C. (2006). "Florida y Boedo: Hostilidades y acuerdos." In G. Montaldo \& D. Viñas, eds. Literatura argentina siglo XX. Yrigoyen entre Borges y Arlt (1916-1930). Buenos Aires, Fundación Crónica Genera. pp. 44-58.

Gramuglio, M. T. (2002). "El realismo y sus destiempos en la literatura Argentina." In M. T. Gramuglio, ed. Historia Crítica de la Literatura Argentina (Vol. 6). Buenos Aires, Emecé.

Jordan, P. D. (2006). The Author in the Office. Narrative Writing in Twentieth-Century Argentina and Uruguay. Woodbridge, Tamesis.

King, J. (1986). Sur. A Study of the Argentine Literary Journal and its Role in the Development of a Culture, I93 I-1970. Cambridge, Cambridge U P.

“La unión de escritores proletarios." (I932). Actualidad, I (2), p. 46.

Laera, A. (20I4). Ficciones del dinero: Argentina, I 890-200 I. Buenos Aires, Fondo de cultura económica. 
Lamborghini, O. (1995). “The Proletarian Boy.” Delos, 6 (I), pp. 74-8 I.

Lamborghini, O. (2003). “El niño proletario.” In C. Aira, ed. Novelas y cuentos. Buenos Aires, Sudamericana, pp. 56-62.

Larsen, N. (1995). Reading North by South. On Latin American Literature, Culture, and Politics. Minneapolis, U of Minnesota P.

Leland, C. T. (I986). The Last Happy Men. The Generation of I922, Fiction and the Argentine Reality. New York, Syracuse U P.

Mariani, R. (I927). "La extrema izquierda.” In P. J. Vignale \& C. Tiempo, eds. Exposición de La Actual Poesía Argentina, I922-I927. Buenos Aires, Minerva, pp. x-xi.

Mariani, R. (I924). “Martin Fierro y Yo.” Martin Fierro, (7).

Mariani, R. (2008). Cuentos de la oficina. In R. Carbone \& A. Ojeda Bär, eds. Roberto Mariani. Obra complete 1920-I930. Buenos Aires, El 8vo. loco Ediciones, pp. I27-2 I6.

Masiello, F. (1992). Between Civilization and Barbarism. Women, Nation and Literary Culture in Modern Argentina. London, U of Nebraska P.

Montaldo, G. (2006). "Literatura de izquierda: Humanitarismo y pedagogía.” In D. Viñas \& G. Montaldo, eds. Literatura argentina siglo XX. Yrigoyen entre Borges y Arlt. Buenos Aires, Fundación Crónica Genera, pp. 324-344.

Moya, J. C. (1998). Cousins and Strangers. Spanish Immigrants in Buenos Aires I850-I930. Berkeley, U of California P.

Nilsson, M. (20I7). "The Making of Swedish Working-Class Literature." In M. Nilsson \& J. Lennon, eds. Working-Class Literature(s). Historical and International Perspectives. Stockholm, Stockholm U P, pp. 95-I 27.

Olivari, N. \& Stanchina, L. (I924). Manuel Gálvez. Ensayo sobre su obra. Buenos Aires, Agencia General de Libreria y Publicaciones.

Portantiero, J. C. (I96I). Realismo y realidad en la narrativa argentina. Buenos Aires, Ediciones Procyón.

Rama, Á. (I996). The Lettered City. Durham, Duke U P.

Rabinowitz, P. (I99I). Labor and Desire. Women's Revolutionary Fiction in Depression America. Chapel Hill, U North Carolina P. 
"Resoluciones." (1932). Ahora! Edición de La Unión de Escritores Proletarios, I (I), p. 2.

Rock, D. (1975). Politics in Argentina, I 890-1930. The Rise and Fall of Radicalism. Cambridge U P.

Rodríguez, F. \& Laera, A. (20I9). "El cuerpo del trabajo." A Contracorriente. Una Revista de Estudios Latinoamericanos, I6 (3), pp. 3 I-38.

Rodríguez Pérsico, A. (2013). "Capitalismo y exclusión. Elías Castelnuovo y la búsqueda de una lengua heterogénea,". In E. Castelnuovo. Larvas. Buenos Aires, Biblioteca Nacional, pp. 9-84.

Rubione, A. (I980). "El lugar del artista. Entrevista a Osvaldo Lamborghini." Lecturas Críticas. Revista de Investigación y Teorías Literarias, I (I), pp. 48-5 I.

Saítta, S. (2000). El escritor en el bosque de ladrillos. Una biografía de Roberto Arlt. Buenos Aires, Editorial Sudamericana.

Saítta, S. (2008). "Elías Castelnuovo, entre el espanto y la ternura.” In Á. F. Bolaños, G. C. Nichols \& S. Sosnowski, eds. Literatura, politica y sociedad. Construcciones de sentido en la Hispanoamérica contemporánea. Homenaje a Andrés Avellaneda. Pittsburgh, Biblioteca de América, pp. 99-I I3.

Sarlo, B. (1988). Una modernidad periférica. Buenos Aires, I920 y I930. Buenos Aires, Ediciones Nueva Visión.

Sommer, D. (I989). "Foundational Fictions. When History Was Romance in Latin America." Salmagundi, 82/83, pp. I I I-I 4 I.

Sorbille, M. (2016). "El matadero". Una pesadilla. En busca del falo perdido con las topologías de Freud, Lacan y Zizek. Buenos Aires, Editorial Biblos.

Tarcus, H. ed. (2007). Diccionario biográfico de la izquierda argentina. De los anarquistas a la "nueva izquierda" I870-1976. Buenos Aires, Emecé.

“Unión de escritores proletarios." (I932). Actualidad, I (4), pp. 45-46.

Unruh, V. (I 994). Latin American Vanguards. The Art of Contentious Encounters. Berkeley, U of California P.

Verani, H. J. (I996). Narrativa vanguardista hispanoamericana. Mexico City, U Nacional Autónoma de México. 
Viñas, D. (197I). De Sarmiento a Cortázar. Literatura argentina $y$ realidad política. Buenos Aires, Siglo Veinte.

Viñas, D. (1973). Grotesco, inmigración y fracaso. Armando Discépolo. Buenos Aires, Ediciones Corregidor.

Volland, N. (2009). "Inventing a Proletarian Fiction for China. The Stalin Prize, Cultural Diplomacy, and the Creation of a PanSocialist Identity.” In T. Vu \& W. Wongsurawat, eds. Dynamics of the Cold War in Asia: Ideology, Identity, and Culture. New York, Palgrave, pp. 93-I25.

Yunque, A. (194I). La literatura social en la Argentina. Historia de los movimientos literarios desde la emancipación nacional hasta nuestros dias. Buenos Aires, Claridad. 